\title{
Retrofitting Measures of Guntupalli Caves, West Godavari District, Andhra Pradesh, India, using Reinforced Rock Technique
}

\author{
S.R.K.Reddy, A.Satish Kumar, P.Urmila
}

\begin{abstract}
India is known for its rich, diversified and cultural properties. Assessment, evaluation and maintenance of ancient and historical monuments is a major concern today. Most of the historical structures which were built in earlier 1950s are now found unsafe if cheeked by present codes. Disintegration / deterioration due to continuous weathering processes and bitter failure examples from recent natural hazards reveal the importance of restoration / retrofitting measures.

In this paper, a case study on Guntupalli Caves, one of the finest testimonials of Buddhist Heritage, located in eastern ghat region of A.P. state, India, is taken up. The important monuments located in the study area are rock cut temples, monasteries and ruined Mandapa. Rock samples of different monuments are collected and tested in the laboratory and from test results, it is observed that the compressive and bending stress values are low and found vulnerable against any further loading. A new retrofit concept "Reinforced Rock" technique is adopted by introducing steel flats / bars in tension zone of rock samples. Test results have shown that compression and bending stress values are increased by two to four times compared with the results of those obtained in rock samples without reinforcement.
\end{abstract}

Index Terms- Rock cut monument, retrofit technique, Reinforced rock, bending stress.

\section{INTRODUCTION}

India is possessed with one of the oldest civilizations in the world and its past heritage and cultural wealth have been the subject of interest of the entire humanity. The spirit of Antiquarianism in India was best represented by the Asiatic Society of Bengal, founded in 1784 by William Jones. In 1861, the Archaeological Survey of India (ASI) was established and started as a mission and functioning towards the cause of protection, preservation and conservation of built heritage and antiquarian remains of India. India is an active member on world heritage from 1977 and has been working in close co-operation with various international agencies from different parts of the world.

Besides ASI, State Governments, Universities, Research Organizations and District local administrations are also working in these conservative programs.

Cave monuments claim their due share in the heritage properties as they were in the form of shelters/dwellings for

Revised Manuscript Received on August 19, 2019.

Dr.S.R.K.Reddy Professor, Department of Civil Engineering, Gudlavalleru Engineering College, Gudlavalleru, Andra Pradesh, India. (Email: srkrsatty@gmail.com)

A.Satish Kumar, Assistant Professor, Department of Civil Engineering, Aditya Engineering College, Surampalem, Andra Pradesh, India. (Email: suryasatish111@gmail.com)

P.Urmila, Assistant Professor, Department of Civil Engineering, NRI Institute of Technology, Agiripalli, Andra Pradesh, India. (Email: pallepamulaurmila@gmail.com) human beings right from stone-age to hermitage. Throughout the history, primitive people have made use of caves for shelter, burials such as rock - cut - tombs or as religious sites.

Cave heritage can be broadly categorized into natural caves, temples/ monuments built in natural caves and rock-cut built caves / monuments along low level hill slopes. The present study of Guntupalli Caves [1] falls under the category of rock - cut caves.

Rock - Cut caves are built only by generations of religious nature and mostly confined to East and Southeast Asian countries.

The heritage properties are exposed to natural weathering actions and man- made disasters which threaten their integrity and values. Since these are on the verge of extinction due to hostile conditions of weather, encroachments in the name of development works, it is now the sacred duty of anybody to safe guard them from all odds.

The real challenge is to identify the protective measures and conservation of such historical monuments [2]-[4] with a view to assure the survival of these cultural heritage for centuries to come, with a little change as possible, but without altering the authenticity of their original appearance and character.

\section{Project Outline}

Guntupalli Caves are widely acclaimed as one of the finest and beautiful sites in the Eastern ghat region. The archaeological site under study is located about $45 \mathrm{Km}$ north of Eluru, West Godavari District, Andhra Pradesh, India. The location map of the study area is presented in Fig.1

The beautiful conglomeration of these monuments is constructed with great reverence by Buddhist community in the oldest centuries. The epigraphical records mention that these caves dates back to the ancient periods of $3^{\text {rd }}-2^{\text {nd }}$ century to $5^{\text {th }}$ to $6^{\text {th }}$ century A.D. The main significance of these sites is that the age of some of the monuments pre-dates even world heritage sites of Ajanta and Ellora caves of Maharashtra. The display of superb craftsmanship of these antiquities is also termed as "Ajanta of Andhra Pradesh". These caves were excavated along the slopes of the fragile sand stone hills of upper Gondwana formations. 


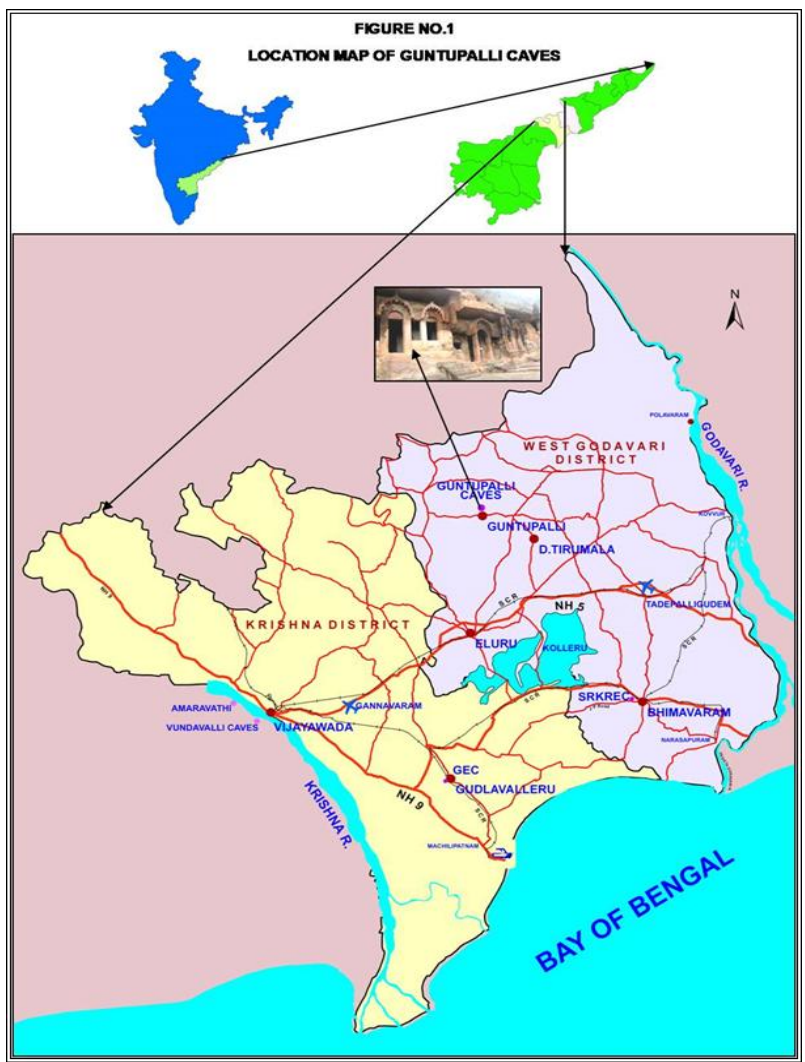

Fig.1 Location Map of Guntupalli Caves

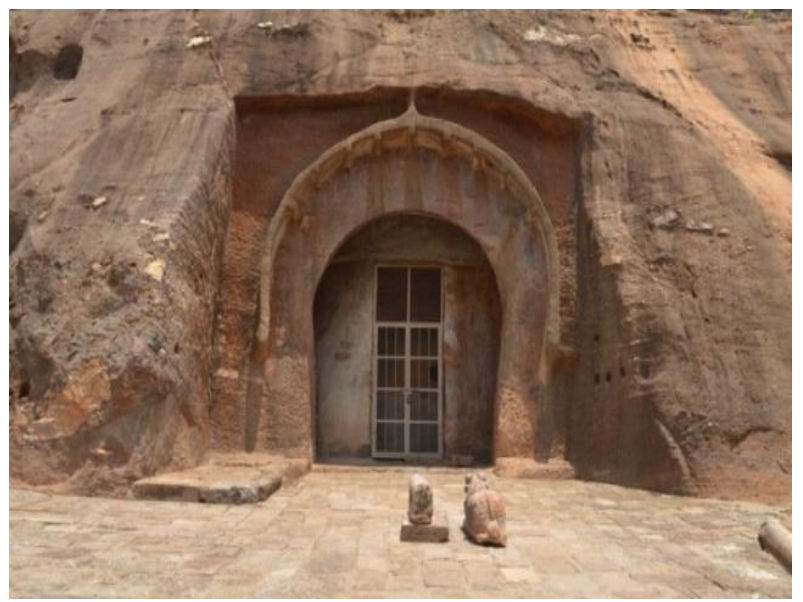

Fig. 2 Facade of rock cut temple

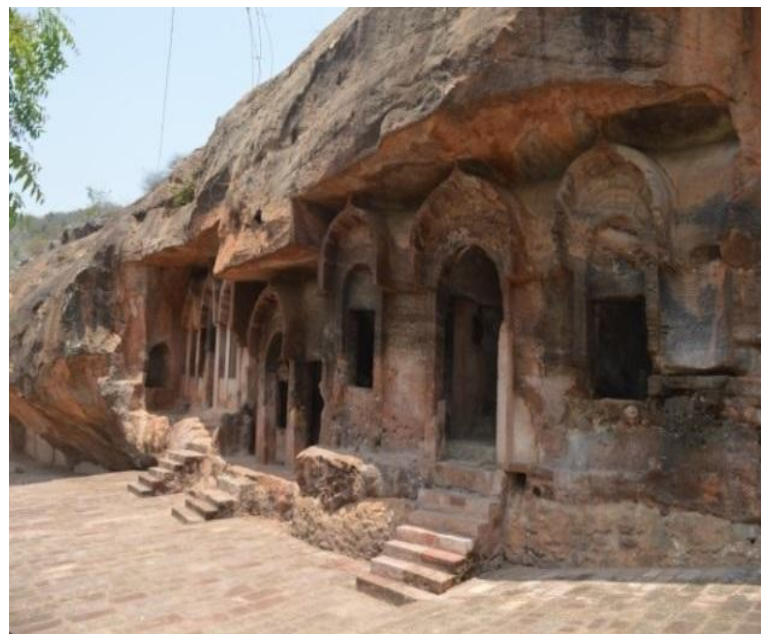

Fig. 3 View of large monastery

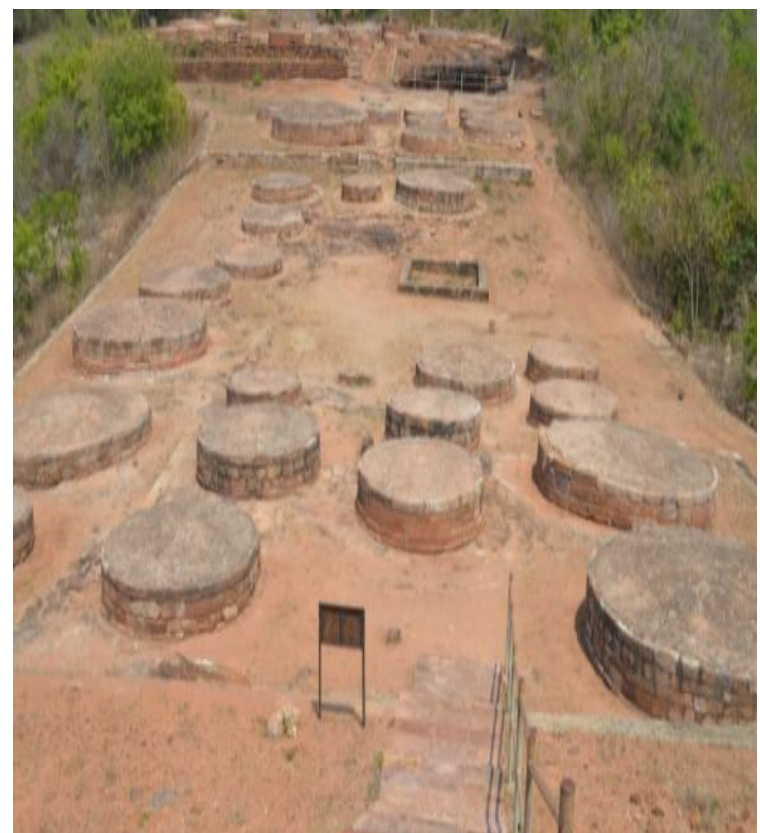

Fig. 4 Group of Stupas

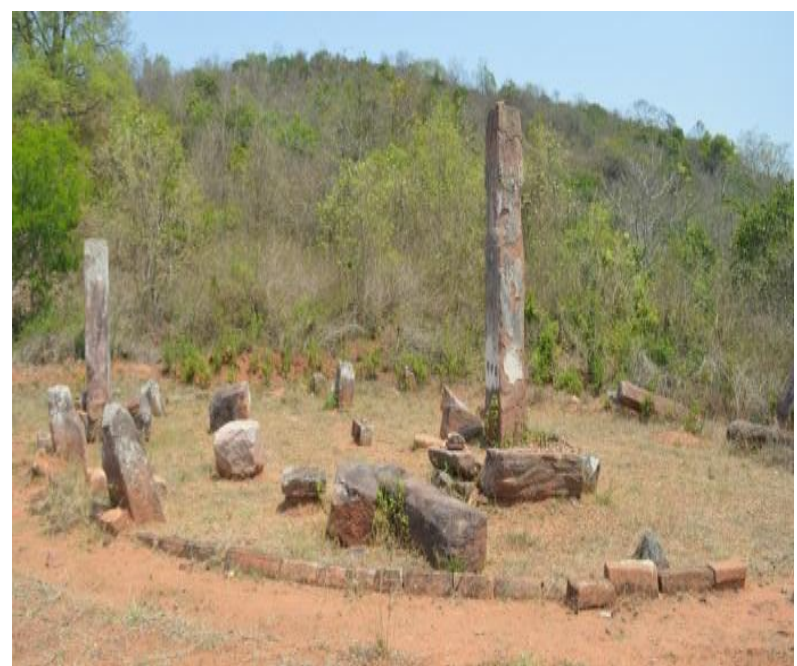

Fig. 5 View of ruined Mandapa

The type of structures / monuments in this site include mostly Rock-cut temples, monasteries, sacred stupas, ruined Mandapa etc., as depicted in Figs. 2 to 5

The facade and interior design are the finest specimens of Indian Rock-cut architecture. These caves and other monuments are being subjected to various weathering processes for almost more than two millenniums and are in different stages of disintegration / deterioration. Some of the monuments are worn-out and some are in a sad state of disrepair. The surface of temple structures, sculptural features have shown extensive distress.

\section{METHODOLOGY \& RESULTS}

Arch construction covers a span without generating tensile stresses. Strong supports / abutments are necessary for development of arch action. Even missing one link can upset the entire arch action. When abutment slacks over a period of time, it results introducing bending moments and stresses in

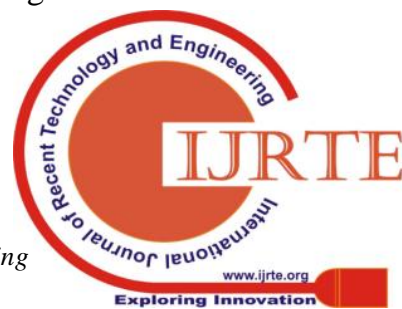


the structure for which it was not designed. The structural characteristics such as joint rigidity and safe bearing capacity of the ground may change with time. These changes shall affect the integrity of monuments.

It is highly appropriate to assess and evaluate the existing status of monuments, collect rock samples of different monuments and laboratory studies are need to be initiated whether retrofit measures are required or not, before its transfer for field application.

\section{A. Reinforced Rock technique}

Reinforced Rock technique [5] is one of the most recently developed technique with which multiple failure problems can be solved; particularly to enhance the compressive and bending stress values of Rock cut monuments.

The word "Reinforcing" means to strengthen one material by introducing another material. As an example, Reinforced Concrete is primarily a composite material introducing steel in tension zone since concrete is weak in tension and thus it resists high values of tensile stresses.

The present study focuses on strength parameters of stone and rock - cut monuments which are very brittle in nature and are very weak in tension. Safeguarding these monuments just by using preservation and repairing techniques [6], [7] may not suitable at all times as they were contrived thousands of years ago and some of them were already in a state of distress. Hence, there is an immediate need to apply innovative retrofitting measures to increase the strength of existing monuments; particularly in tension and bending modes of failure.

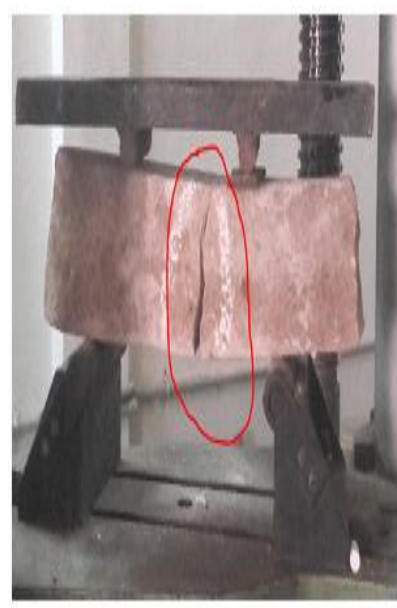

(a.) Without Reinforcement

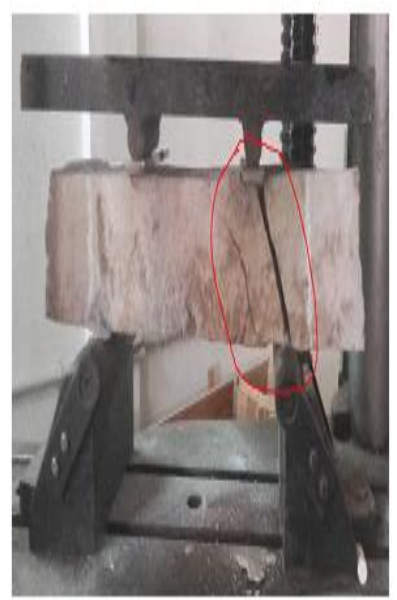

b.) With Reinforcement
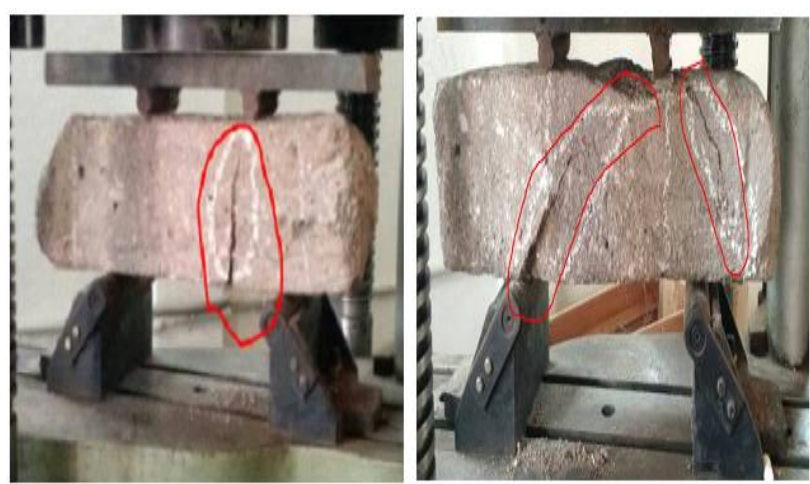

(a.) Without Reinforcement (b.) With Reinforcement Fig. 7 Testing of Model Beam - B Fig. 6 Testing of

In order to provide extra strength in flexural tension zones of rock - cut beams and columns, the concept of "Reinforced Rock" is proposed in the present investigation. The methodology suggests to provide some reinforcement in tension zone of rock either in form of steel rods or steel flats to take tensile stresses caused due to bending or direct tensile loads. In concrete, the reinforcement is provided in the form of grill work before concrete is poured; whereas in rock, it is done by making grooves on tension face and the required reinforcing rods or flats are placed in the groove and the groove is then filled with adhesive or some grouting material whose strength is not less than the original rock strength.

\section{B. Collection and Testing of Rock Samples}

Rock samples were collected from three types of monuments; Rock - Cut Cave (Sample - 1), Votive Tomb (Sample - 2), and Ruined Mandapa (Sample - 3), so as to identify the type of rock, its characteristics and compressive strengths. With machine grinding, cube samples are prepared and tested in laboratory. The test results of compressive strengths are presented in Table I.

Table I Compressive Strength of Rock Samples

\begin{tabular}{|c|c|c|c|}
\hline S.No & Type of Rock & Sample & $\begin{array}{c}\text { Compressi } \\
\text { ve } \\
\text { Strength } \\
\left(\mathrm{N} / \mathbf{m m}^{2}\right)\end{array}$ \\
\hline 1 & Cave Rock & $\begin{array}{c}\text { Sample }- \\
1\end{array}$ & 6.93 \\
\hline 2 & Votive Tomb Rock & $\begin{array}{c}\text { Sample }- \\
2\end{array}$ & 5.54 \\
\hline 3 & $\begin{array}{c}\text { Mandapa Pillar } \\
\text { Rock }\end{array}$ & $\begin{array}{c}\text { Sample }- \\
3\end{array}$ & 2.10 \\
\hline
\end{tabular}

From test results it is shown that the strength of Mandapa Rock material (Sample - 3) is low compared to other two rocks of Caves and Votive Tombs. It is also observed that the Kondalite formation of Mandapa rock is highly affected by environment and weathering action.

In Monasteries, there are many openings for doors and windows on which rock - cut lintel beams are provided. In ruined Mandapa, openings between rock pillars were also covered by rock - cut beams which normally be subjected to bending stresses.

Rock samples of beams were collected from two types of monuments; one from Monastery having characteristics of rock with mixture of sand stone and lime stone with smooth texture (Model $-\mathrm{A}$ ) and the other from ruined Mandapa having characteristics of sand stone with porous texture (Model - B) and beam models of size 500 x 100 x $100 \mathrm{~mm}$ were prepared. One set of beam samples were then grooved to a depth of $60 \mathrm{~mm}$ and width $40 \mathrm{~mm}$ on the assumed tension face. M.S flat of size $40 \mathrm{~mm}$ wide and $4 \mathrm{~mm}$ thick is then inserted into the groove and the remaining portion was filled with "Polyester resign grout". Another set of same beam samples were prepared without providing groove or reinforcing flats.

These two sets of beam samples with and without reinforcement of beam Models A \& B were tested for flexure

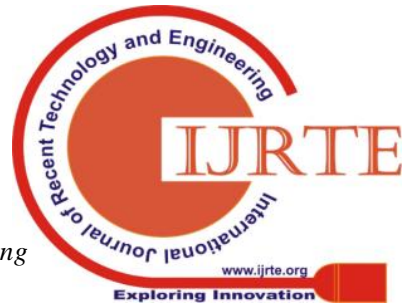


as shown in Figs. $6 \& 7$ and the results are presented in Table II

Table II Flexural Strength of Beam Models

\begin{tabular}{|c|c|c|c|}
\hline \multirow{2}{*}{ S.No } & \multirow{2}{*}{$\begin{array}{c}\text { Type of } \\
\text { Model }\end{array}$} & \multicolumn{2}{|c|}{$\begin{array}{c}\text { Flexural Strength }\left(\mathbf{N} / \mathbf{m m}^{2}\right) \\
\text { Without }\end{array}$} \\
\cline { 3 - 4 } & Reinforcement & $\begin{array}{c}\text { With } \\
\text { Reinforcement }\end{array}$ \\
\hline 1 & Model - A & 3.161 & 5.234 \\
\hline 2 & Model - B & 3.140 & 12.000 \\
\hline
\end{tabular}

From the test results, it is observed that for Beam Model A, the flexure strength with reinforcement is increased by 1.65 times of the Beam Model - A without reinforcement; whereas for Beam Model - B, the flexural strength with reinforcement is increased by 4 times the Beam Model without reinforcement.

\section{CONCLUSIONS}

- Prior to retrofitting measures, assessment and evaluation of various parameters like structural and geomorphological features of the study area are necessary.

- Satellite Remote Sensing data analysis is to be carried out to identify the reasons of deterioration of Heritage Monuments.

- 'Reinforced Rock' technique provides more strength in tension zones of rock samples when they are used as beams or columns.

- Flexure strength of reinforced rock material is found two to four times greater than the strength of same rock without reinforcement.

\section{REFERENCES}

1. "Buddhist Monuments Guntupalli Caves" ssredy.peram@yahoo.com under A.P Tourism and Temples in Andhra Pradesh.

2. Croci G (2000), "General Methodology for Structural Restoration of historic buildings: The cases of Tower of Pisa and the Basilica of Assis; Journal of Cultural Heritage Vol.1, issue 1, January 2000, pp. 7 - 18

3. Dr.T.S.Sridhar and R.Narayanan "Deterioration of Monuments and their Preservations" - A report from dept. of Archaeology, Govt. of Tamilnadu.

4. Gioegio C. Chawley (2001), "Conserving the Temple of Lord Jagannath”, Marg Publications, Vol.52

5. Panduranaga Rao. M (1987) "Geotechnical Appraisal and Evaluation of Kakatiya Monuments, Warangal, A.P” - A research report for Archaeological Survey of India, Govt. of India, New Delhi.

6. Pere Roca (2011), "Restoration of Historic Buildings: Conservation principles and structural assessment". International Journal of Materials and Structural Integrity 2011, Vol-5, No. 2 -3, pp. 151 - 167; ISSN; 1745 - 0055 Indersciences Enterprises Ltd. Country of Publications, U.K

7. Sayali Sandbhor and Rohan Botre (2013) "A Systematic Approach towards Restoration of Heritage Buildings - A Case Study, "IJRET Vol.02, Issue:03, March - 2013, pp. 229-238 